\title{
KAJIAN PUSTAKA GAMBARAN POLA ASUH DAN STATUS GIZI ANAK UMUR 0 - 24 BULAN
}

\author{
Mahdaniah. N.P. Ginting ${ }^{1}$, Haripin Togap Sinaga ${ }^{2}$ \\ Poltekkes Kemenkes Medan \\ e-mail: ${ }^{1}$ mahdaniahnurputriginting@gmail.com, ${ }^{2}$ haripinsinaga@yahoo.com
}

\begin{abstract}
Nutritional status is a factor that affects the quality of human resources, lack of nutrients during the growth period can have an impact on the delay in physical growth, motor and cognitive development. Parents' upbringing plays an important role in overcoming nutritional problems in children, especially in the parenting style of breastfeeding and feeding patterns. The aim of this research was to know the description of parenting style and nutritional status of children aged 0-24 months. This type of research was library research (library research). The data collection method used Google Scholar, Garuda and Arjuna databases. Researchers used 15 articles published from 2015 - 2020 and indexed in Sinta, Arjuna, Mendeley, Google Scholar, Scimago, Worldcat, Zotero, Rama repository, DOAJ, IPI, Garuda, Dimensions, Crossref. The results of this study obtained the percentage of children's nutritional status in accordance with the articles listed, namely $67.5 \%$ good nutrition, $8.4 \%$ under nutrition, $10.4 \%$ short, $6.7 \%$ thin. The pattern of care for children, namely there wre children who get breastmilk as much as $68.4 \%$ and children who did not get breastmilk as much as $31.6 \%$ and the lack of knowledge of mothers in providing complementary foods with breastfeeding, mothers who provide complementary foods to children $46.6 \%$ and those who did not provide complementary breastfeeding to children $53.3 \%$.
\end{abstract}

Keywords: Parenting style; nutritional status

\begin{abstract}
ABSTRAK
Status gizi merupakan faktor yang mempengaruhi kualitas sumber daya manusia, kekurangan zat gizi selama masa pertumbuhan dapat berdampak pada keterlambatan pertumbuhan fisik, perkembangan motorik dan kognitif. Pola asuh orang tua memegang peranan penting dalam mengatasi permasalahan gizi anak terkhususnya pada pola asuh pemberian ASI dan pola asuh pemberian makan. Tujuan penelitian ini mengetahui gambaran pola asuh dan status gizi anak umur 0 - 24 bulan. Jenis penelitian ini adalah penelitian kepustakaan (library research). Metode pengumpulan data menggunakan database Google Scholar, Garuda dan Arjuna. Peneliti menggunakan 15 artikel yang diterbitkan dari tahun 2015 - 2020 dan terindeks di Sinta, Arjuna, Mendeley, Google Scholar, Scimago, Worldcat, Zotero, Rama repository, DOAJ, IPI, Garuda, Dimensions, Crossref. Hasil penelitian ini mendapatkan persentase status gizi anak sesuai dengan artikel yang tercantum yaitu gizi baik sebanyak 67.5\%, gizi kurang $8.4 \%$, pendek $10.4 \%$, kurus $6.7 \%$. Pola asuh terhadap anak yaitu terdapat anak yang mendaptkan ASI sebanyak $68.4 \%$ dan anak yang tidak mendaptkan ASI sebanyak $31.6 \%$ dan kurangnya pengetahuan ibu dalam memberikan makanan pendamping ASI, ibu yang memberikan MP-ASI kepada anak $46.6 \%$ dan yang tidak memberikan MP-ASI kepada anak $53.3 \%$.
\end{abstract}

Kata kunci: Pola asuh,; status gizi

\section{PENDAHULUAN}

Status gizi merupakan faktor yang mempengaruhi kualitas sumber daya manusia, kekurangan zat gizi selama masa pertumbuhan dapat berdampak pada keterlambatan pertumbuhan fisik, perkembangan motorik dan kognitif. Pola asuh orang tua memegang peranan penting dalam mengatasi permasalahan gizi anak terkhususnya pada pola asuh pemberian ASI dan pola asuh pemberian makan. Tujuan penelitian ini mengetahui gambaran pola asuh dan status gizi anak umur 0 - 24 bulan. Jenis penelitian ini adalah penelitian kepustakaan (library research). Metode pengumpulan data menggunakan database Google Scholar, Garuda dan Arjuna. Peneliti menggunakan 15 artikel yang diterbitkan dari tahun 2015 - 2020 dan terindeks di Sinta, Arjuna, Mendeley, Google Scholar, Scimago, Worldcat, Zotero, Rama repository, DOAJ, IPI, Garuda, Dimensions, Crossref. Hasil penelitian ini mendapatkan persentase status gizi anak sesuai dengan artikel yang tercantum yaitu gizi baik sebanyak $67.5 \%$, gizi kurang $8.4 \%$, pendek $10.4 \%$, kurus $6.7 \%$. Pola asuh terhadap anak yaitu terdapat anak yang mendaptkan ASI sebanyak $68.4 \%$ dan anak yang tidak mendaptkan ASI sebanyak $31.6 \%$ dan kurangnya pengetahuan ibu dalam memberikan 
makanan pendamping ASI, ibu yang memberikan MP- . Jumlah sampel pada setiap artikel bervariasi mulai ASI kepada anak 46.6\% dan yang tidak memberikan dari 15 hingga 102 orang.

MP-ASI kepada anak $53.3 \%$.

Kata kunci: Pola asuh,; status gizi

Tabel 4. Kriteria Inklusi dan ekslusi berdasarkan PICOS

\begin{tabular}{|c|c|c|}
\hline Kriteria & Inklusi & Eksklusi \\
\hline $\begin{array}{l}\text { Populasi/ } \\
\text { problem }\end{array}$ & $\begin{array}{l}\text { Anak umur } 0-24 \\
\text { bulan }\end{array}$ & $\begin{array}{l}\text { Anak umur } 2 \\
\text { tahun keatas }\end{array}$ \\
\hline Intervensi & $\begin{array}{ll}\text { Tidak } & \text { ada } \\
\text { intervensi } & \end{array}$ & Ada intervensi \\
\hline Comparasi & $\begin{array}{ll}\text { Tidak } & \text { ada } \\
\text { pembanding }\end{array}$ & Ada pembanding \\
\hline Study design & $\begin{array}{l}\text { Mix methods } \\
\text { studi, } \\
\text { experimental } \\
\text { studi, quasi } \\
\text { experimen, cross } \\
\text { sectional studi, } \\
\text { analisi univariat, } \\
\text { analisis bivariat, } \\
\text { kualitatif studi }\end{array}$ & $\begin{array}{l}\text { Longitudinal, } \\
\text { Randomized } \\
\text { control trial dan } \\
\text { bentuk lain selain } \\
\text { dari kriteria } \\
\text { inklusi }\end{array}$ \\
\hline Full text & Lengkap dan free & $\begin{array}{l}\text { Tidak lengkap } \\
\text { dan berbayar }\end{array}$ \\
\hline Indeks Jurnal & $\begin{array}{l}\text { Bereputasi } \\
\text { nasional, seperti } \\
\text { Google scholar, } \\
\text { Portal garuda, } \\
\text { Arjuna }\end{array}$ & $\begin{array}{l}\text { Tidak bereputasi } \\
\text { nasional }\end{array}$ \\
\hline Bahasa & Indonesia & $\begin{array}{ll}\text { Selain } & \text { bahasa } \\
\text { Indonesia } & \end{array}$ \\
\hline Tahun terbit & $\begin{array}{ll}\text { Mulai tahun } \\
2015-2020\end{array}$ & $\begin{array}{l}\text { Sebelum tahun } \\
2015\end{array}$ \\
\hline
\end{tabular}

\section{A. Hasil pencarian jurnal}

Dari hasil pencarian dengan menggunakan tiga database pencari literature, total pustaka yang ditemukan sebanyak 358 artikel, kemudian dilakukan skrining menurut enam kriteria inklusi dan pada tahan akhir diperoleh 15 artikel dalam bentuk pdf full teks

\section{HASIL}

\section{A. Karakteristik Studi}

Terdapatlima belas artikel tentang Gambaran pola asuh dan status gizi anak pada umur 0-24 bulan yang terbit pada jurnal nasional mulai tahun 2015 hingga tahun 2020.Lima belas artikel tersebut terindeks oleh, Sinta, Arjuna, Mendeley, Google Scholar, Scimago, Worldcat, Zotero, Rama repositor DOAJ, IPI, Garuda, Dimensions, Crossref. Adapun nama-nama jurnal tersebut yaitu :Jurnal Gizi Indonesia, Jurnal Gizi dan Kesehatan, Jurnal Gizi Universitas Muhammadiyah Semarang, Jurnal GIZIDO, Jurnal Gizi Klinik Indonesia, Skripsi Diploma thesis Universita Andalas, Jurnal Kesmas dan (JKG), Amerta Nutrition (2020), Aceh Nutrition Jurnal

\section{B. Karakteristik Responden}

Dari 15 artikel yang dikaji, jumlah responden ibu sebanyak 632 orang. Sebagian besar responden dalam penelitian yang dikaji adalah ibu-ibu yang mempunyai anak umur 0-24 bulan, bekerja sebagai ibu rumah tangga, responden memiliki usia produktif yaitu umur 20-40 tahun. Pekerjaan suami sebagian besar sebagai wiraswasta, pegawai negeri dan pegawai swasta. Hanya sebagian kecil suami yang tidak memiliki pekerjaan.

Jumlah balita yang menjadi sampel dalam 15 penelitian berjumlah 756 orang. Karakteristik gender tidak ditentukan baik itu laki-laki atau pun perempuan.

C. Pola asuh orang tua sebagai penunjang status gizi anak

\section{Status gizi}

Status gizi adalah keadaan tubuh sebagai akibat konsumsi makanan dan penggunaan zat-zat gizi. Penelitian ini menggunakan indikator status gizi, yaitu gizi baik, gizi kurang, pendek dan kurus. Berdasarkan penelusuran 15 artikel ilmiah, 4 diantaranya mengenai status gizi. Persentase status gizi anak yang diperoleh berdasarkan 4 artikel ilmiah yaitu gizi baik sebanyak $67.5 \%$, gizi kurang $8.4 \%$, pendek $10.4 \%$, kurus $6.7 \%$.

2. Pola asuh pemberian ASI

ASI merupakan makanan yang terbaik untuk bayi namun cakupan ASI Eksklusif masih tidak sesuai dengan standar target nasional (minimal 80\%). Pemberian Air Susu Ibu (ASI) atau menyusui bayi dilakukan berbagai lapisan masyarakat di seluruh dunia, karena banyak manfaatnya yang diperoleh dari ASI Eksklusif dan praktik menyusui selama 2 tahun.

Tabel Distribusi Pemberian ASI

\begin{tabular}{|l|l|l|l|}
\hline $\begin{array}{l}\mathrm{N} \\
\mathrm{o}\end{array}$ & $\begin{array}{l}\text { Respond } \\
\text { en }\end{array}$ & $\begin{array}{l}\text { Yang } \\
\text { mendapatkan } \\
\text { ASI }\end{array}$ & $\begin{array}{l}\text { Yang tidak } \\
\text { mendapatkan } \\
\text { ASI }\end{array}$ \\
\hline 1 & 53 anak & $62.3 \%$ & $37.7 \%$ \\
\hline 2 & 68 anak & $72.8 \%$ & $27.2 \%$ \\
\hline 3 & 65 anak & $59.1 \%$ & $40.9 \%$ \\
\hline 4 & 75 anak & $79.4 \%$ & $20.6 \%$ \\
\hline & Rata-rata & $68.4 \%$ & $31.6 \%$ \\
\hline
\end{tabular}

3. Pola asuh pemberian makan

Pemberian MP-ASI yang tepat sebaiknya di mulai saat usia bayi 6 bulan. Pola asuh ibu dalam pemberian makan (MP-ASI) ke anak masih kurang. Ibu yang memberikan MP-ASI kepada anak adalah $46.6 \%$ yang tidak memberikan MP-ASI 53.3\%. 
Tabel 5. Ringkasan Isi Jurnal

\begin{tabular}{|c|c|c|c|c|}
\hline No & $\begin{array}{l}\text { Penulis, judul, jurnal, } \\
\text { tahun terbit, indeks }\end{array}$ & $\begin{array}{l}\text { Bentuk studi, jumlah } \\
\text { sampel, variable dan } \\
\text { analisis }\end{array}$ & Tujuan dan hasil & Database \\
\hline 1. & $\begin{array}{l}\text { Rachma Purwant, Erna } \\
\text { Kusuma, Setiyowati } \\
\text { Karakteristik keluarga } \\
\text { yang berhubungan } \\
\text { dengan status gizi balita } \\
\text { umur 6-59 bulan } \\
\text { Jurnal Gizi Indonesia } \\
\text { (ISSN:1858-4942). Vol. } \\
\text { 5, No.1, Desember } 2016 \\
\text { Arjuna, Google Scholar, } \\
\text { Mendeley }\end{array}$ & 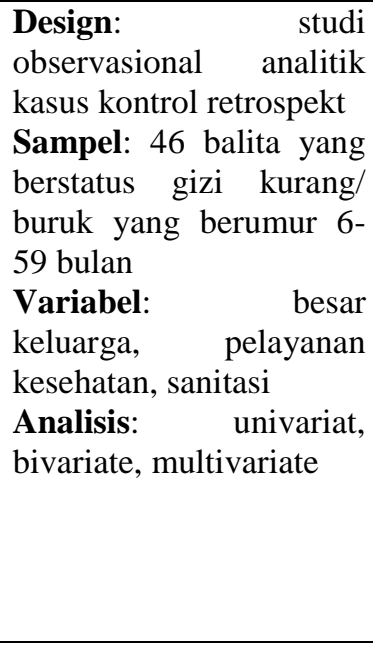 & $\begin{array}{l}\text { Tujuan : Menganalisis hubungan } \\
\text { antara karakteristik keluarga } \\
\text { dengan status gizi balita di } \\
\text { wilayah Puskesmas II Sumbang, } \\
\text { Kabupaten Banyumas } \\
\text { Hasil : Berdasarkan hasil } \\
\text { penelitian diketahui bahwa } \\
\text { karakteristik keluarga yang } \\
\text { berhubungan dengan status gizi } \\
\text { balita di wilayah Puskesmas II } \\
\text { Sumbang adalah pengetahuan gizi } \\
\text { ibu, sedangkan besar keluarga, } \\
\text { pemanfaatan pelayanan } \\
\text { kesehatan, dan sanitasi } \\
\text { lingkungan tidak berhubungan }\end{array}$ & Arjuna \\
\hline 2. & $\begin{array}{l}\text { Kurnia } \\
\text { Karakteristik dan } \\
\text { Tingkat Pengetahuan } \\
\text { Ibu Nifas Tentang } \\
\text { Inisiasi Menyusui Dini } \\
\text { Jurnal Gizi } \\
\text { dan Kesehatan, } \\
\text { 3(1),2019 } \\
\text { Publish: } 30 \text { juli } 2019 \\
\text { Indeks : Arjuna } \\
\text { Sinta } \\
\text { Scimago, Google } \\
\text { Scholar, Worldcat }\end{array}$ & $\begin{array}{l}\text { Design: deskriptif } \\
\text { Sampel: } 29 \text { orang ibu } \\
\text { nifas yang pernah } \\
\text { melahirkan di praktek } \\
\text { bidan Mandiri Murni } \\
\text { Basri } \\
\text { Variabel: pengetahuan } \\
\text { ibu mengenai inisiasi } \\
\text { menyusui dini } \\
\text { Analisis:univariat, } \\
\text { multivariate chi-square }\end{array}$ & $\begin{array}{l}\text { Tujuan : } \\
\text { Untuk mengetahui karakteristik } \\
\text { dan pengetahuan ibu nifas tentang } \\
\text { inisiasi menyusui dini } \\
\text { Hasil : } \\
\text { Dari hasil penelitian Pengetahuan } \\
\text { ibu nifas tentang Inisiasi } \\
\text { Menyusu Dini (IMD) sebagian } \\
\text { besar dikategorikan masih kurang } \\
\text { khususnya aspek manfaat dan } \\
\text { kandungan ASI hampir sebagian } \\
\text { besar responden menjawab } \\
\text { dengan salah }\end{array}$ & $\begin{array}{l}\text { Portal } \\
\text { Garuda }\end{array}$ \\
\hline 3. & 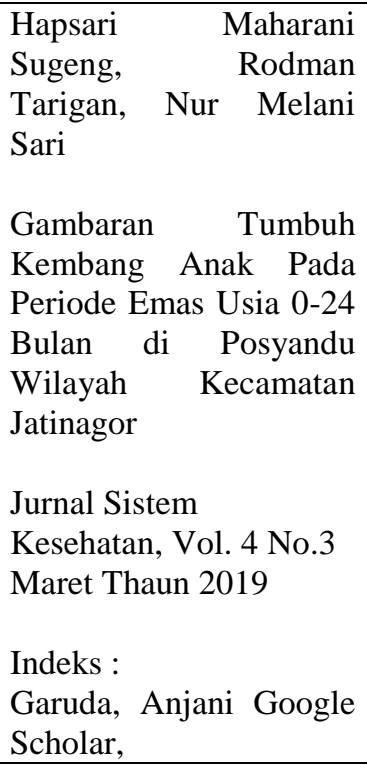 & 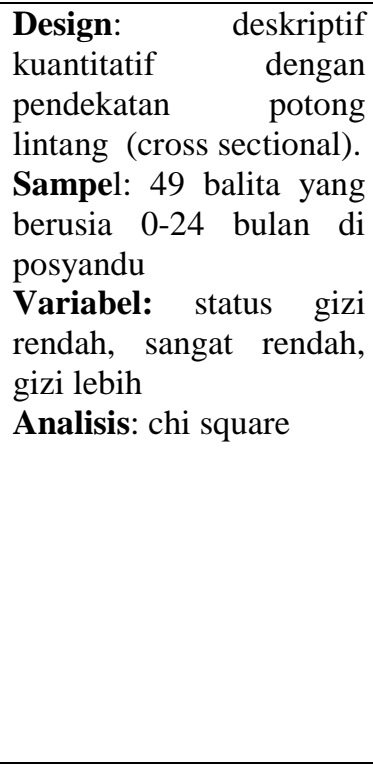 & $\begin{array}{l}\text { Tujuan: } \\
\text { Untuk mengetahui gambaran } \\
\text { tumbuh kembang anak pada } \\
\text { periode emas usia } 0-24 \text { bulan } \\
\text { Hasil : } \\
\text { sebagian besar balita memiliki } \\
\text { pertumbuhan yang normal yaitu } \\
\text { sebanyak 82\%, 6\% mengalami } \\
\text { gizi lebih, } 4 \% \text { beresiko gizi lebih, } \\
4 \% \text { mengalami gizi rendah, } 2 \% \\
\text { balita mengalami gizi sangat } \\
\text { rendah dan } 2 \% \text { balita mengalami } \\
\text { obesitas. Perkembangan yang } \\
\text { diperoleh dengan menggunakan } \\
\text { KPSP adalah } 81,6 \% \text { sesuai, } 12,2 \\
\% \text { balita meragukan, } 6,12 \% \\
\text { terdapat penyimpangan. }\end{array}$ & $\begin{array}{l}\text { Google } \\
\text { Scholar }\end{array}$ \\
\hline 4. & $\begin{array}{l}\text { Rudolf B, Fred A. } \\
\text { Rumangit dan Rugayu }\end{array}$ & $\begin{array}{lr}\text { Design: } & \text { deskriptif } \\
\text { dengan } & \text { desain } \quad \text { cross }\end{array}$ & $\begin{array}{l}\text { Tujuan penelitian ini adalah untuk } \\
\text { mengetahui status gizi bayi usia }\end{array}$ & Arjuna \\
\hline
\end{tabular}




\begin{tabular}{|c|c|c|c|c|}
\hline & $\begin{array}{l}\text { Taher } \\
\text { Status Gizi Bayi 4-6 } \\
\text { Bulan Yang } \\
\text { Mendapatakan ASI } \\
\text { Eksklusif dan Non ASI } \\
\text { Eksklusif di Puskesmas } \\
\text { Kolongan Kecamatan } \\
\text { Kalawat Kabupaten } \\
\text { Minihasa Utara } \\
\text { Jurnal GIZIDO Volume } \\
\text { 10 No.1 Mei 2018 } \\
\text { Indeks : Google Scholar, } \\
\text { DOAJ, Garuda, Sinta }\end{array}$ & $\begin{array}{l}\text { sectional } \\
\text { Sampel: } 53 \text { bayi yang } \\
\text { berusia } 4-6 \text { bulan } \\
\text { Variabel: pemberian } \\
\text { ASI eksklusif dan ASI } \\
\text { non eksklusif, status gizi } \\
\text { (BB/U) } \\
\text { Analisis: uji Chi-square }\end{array}$ & $\begin{array}{l}4-6 \text { bulan yang mendapat ASI } \\
\text { Eksklusif dan ASI non Eksklusif } \\
\text { Hasil : Status gizi bayi } 4-6 \\
\text { bulan di Puskesmas Kolongan } \\
\text { Kecamatan Kalawat Kabupaten } \\
\text { Minahasa Utara yang gizi kurang } \\
7,5 \% \text {, gizi baik } 60,5 \% \text {, dan gizi } \\
\text { lebih } 32 \% \text {. Pemberian ASI } \\
\text { eksklusif sebanyak } 16 \text { bayi, } \\
\text { dengan status gizi baik sebanyak } \\
15 \text { bayi dan gizi kurang sebanyak } \\
1 \text { bayi. Pemberian ASI non } \\
\text { eksklusif sebanyak } 37 \text { bayi, } \\
\text { terbagi atas pemberian susu } \\
\text { formula sebanyak } 20 \text { bayi dengan } \\
\text { status gizi kurang } 1 \text { bayi, gizi baik } \\
7 \text { bayi dan gizi lebih sebanyak } 12 \\
\text { bayi. Pemberian campuran ASI } \\
\text { dan susu formula sebanyak } 17 \\
\text { bayi dengan status gizi kurang } 2 \\
\text { bayi, gizi baik } 10 \text { bayi dan gizi } \\
\text { lebih } 5 \text { bayi. Disarankan }\end{array}$ & \\
\hline 5. & $\begin{array}{l}\text { Nita R. Momongan, } \\
\text { Olfie Sahelangi } \\
\text { Pelatihan MP-ASI } \\
\text { Pangan Berbasis Lokal } \\
\text { Dalam Peningkatan } \\
\text { Pengetahuan Ibu dan } \\
\text { Status Gizi Pada Anak } \\
\text { di Bawah } 2 \text { Tahun di } \\
\text { Wilayah Puskesmas } \\
\text { Kabupaten Minahasa } \\
\text { Tenggara } \\
\text { Jurnal GIZIDO V 10 } \\
\text { No.2 November 2018 } \\
\text { Indeks : Google Scholar, } \\
\text { DOAJ, Garuda, Sinta }\end{array}$ & $\begin{array}{l}\text { Design: } \text { Eksperimen } \\
\text { semu dengan desain } \\
\text { kelompok control pra } \\
\text { dan pasca desain } \\
\text { Sampel: } 70 \text { sampel } \\
\text { terdiri dari kelompok } \\
\text { perlakuan } 35 \text { sampel dan } \\
\text { kelompok control } 35 \\
\text { sampe } \\
\text { Variabel: status gizi } \\
\text { baduta, pengetahuan ibu } \\
\text { mengenai MP-ASI } \\
\text { Analisis: bivariet } \\
\text { menggunakan uji beda } 2 \\
\text { kelompok berpasangan } \\
\text { dan uji beda antar } \\
\text { kelompok }\end{array}$ & $\begin{array}{l}\text { Tujuan: Untuk mengetahui } \\
\text { pengetahuan ibu dan status gizi } \\
\text { baduta sebelum dan sesudah } \\
\text { mendapatkan pelatihan MP-ASI, } \\
\text { makanan berbasispangan di di } \\
\text { Kabupaten Minahasa Selatan } \\
\text { Hasil : Terdapat perbedaan } \\
\text { pengetahuan ibu baduta sebelum } \\
\text { dan sesudah pelatihan pembuatan } \\
\text { MP-ASI berbasis pangan local. } \\
\text { Dan tidak terdapat perbedaan } \\
\text { baduta sebelum maupun sesudah } \\
\text { pemberian MP-ASI berbasis } \\
\text { pangan local }\end{array}$ & Arjuna \\
\hline 6. & $\begin{array}{l}\text { Karlina Nurcahayo dan } \\
\text { Dodik Briawan } \\
\text { Konsumsi Pangan, } \\
\text { Penyakit Infeksi, dan } \\
\text { Status Gizi Anak Balita } \\
\text { Pasca Perawatan Gizi } \\
\text { Buruk } \\
\text { Jurnal Gizi Pangan, } \\
\text { 2016, 5(3) } \\
\text { Indeks : } \\
\text { Arjuna,DOAJ, Google } \\
\text { Scooler }\end{array}$ & $\begin{array}{l}\text { Design: cross-sectional } \\
\text { study } \\
\text { Sampel: } 44 \text { anak balita } \\
\text { yang pernah mendapat } \\
\text { perawatan gizi buruk } \\
\text { Variabel: karakteristik } \\
\text { keluarga, status gizi, } \\
\text { konsumsi pangan dan } \\
\text { supan Energi-Protein, } \\
\text { penyakit infeksi } \\
\text { Analisis: uji korelasi }\end{array}$ & $\begin{array}{l}\text { Tujuan: untuk menentukan } \\
\text { konsumsi makanan, penyakit } \\
\text { menular, dan status gizi anak- } \\
\text { anak di bawah lima tahun setelah } \\
\text { perawatan gizi buruk di } \\
\text { Puskesmas } \\
\text { Hasil : Konsumsi pangan anak } \\
\text { balita pasca perawatan gizi buruk } \\
\text { di Puskesmas masih belum baik. } \\
\text { Kondisi anak balita pasca } \\
\text { perawatan gizi buruk masih } \\
\text { rentan terhadap penyakit infeksi. } \\
\text { Sebagian besar anak mengalami } \\
\text { sakit diare } \geq 3 \text { hari (55.6\%) dan } \\
\text { ISPA } \geq 7 \text { hari (59.3\%). }\end{array}$ & $\begin{array}{l}\text { Google } \\
\text { scholar }\end{array}$ \\
\hline
\end{tabular}




\begin{tabular}{|c|c|c|c|c|}
\hline & & & $\begin{array}{l}\text { Dari ketiga indeks antropometri } \\
\text { sebagian besar anak }(81,5 \%) \\
\text { masih dalam kategori gizi buruk } \\
\text { dan hanya } 18,5 \% \text { yang mengarah } \\
\text { pada perbaikan gizi tingkat } \\
\text { sedang. }\end{array}$ & \\
\hline 7. & $\begin{array}{l}\text { Ratni Ani Margawati, } \\
\text { Bagoes Widjanarko } \\
\text { Pengaruh Status Gizi } \\
\text { dan Asupan Gizi Ibu } \\
\text { Terhadap Berat Bayi } \\
\text { Lahir Rendah Pada } \\
\text { Kehamilan Remaja } \\
\text { Jurnal Gizi Indonesia } \\
\text { (ISSN: 1858-4942) } \\
\text { Vol.5. No. 1, Desember } \\
\text { 2016 } \\
\text { Indeks : Sinta, Garuda, } \\
\text { Zotero, Google Scholar, } \\
\text { DOAJ }\end{array}$ & $\begin{array}{l}\text { Design: observasional } \\
\text { dengan pendekatan } \\
\text { kohort prospektif } \\
\text { Sampel: } 27 \text { orang ibu } \\
\text { hamil trimester lll yang } \\
\text { berumur 16-19 tahun } \\
\text { Variabel: status gizi, } \\
\text { asupan gizi } \\
\text { Analisis: semi FFQ, } \\
\text { asupan zat gizi }\end{array}$ & $\begin{array}{l}\text { Tujuan: Penelitian ini untuk } \\
\text { menganalisis pengaruh status gizi } \\
\text { dan asupan gizi ibu terhadap } \\
\text { BBLR pada kehamilan usia } \\
\text { remaja. } \\
\text { Hasil : Kurang energi kronis } \\
\text { dialami oleh } 66,7 \% \text { ibu hamil usia } \\
\text { remaja, 51,9\% mempunyai } \\
\text { pertambahan berat badan kurang } \\
\text { selama kehamilan, } 59,3 \% \\
\text { mengalami anemia. Rerata asupan } \\
\text { energi, protein, asam folat, zat } \\
\text { besi, seng, vitamin A dan C } \\
\text { subjek berada pada kategori tidak } \\
\text { cukup }\end{array}$ & Portal garuda \\
\hline 8 . & $\begin{array}{l}\text { Livana PH, Mohammas } \\
\text { Fatkhul Mubin, Siti } \\
\text { Marchamatun } \\
\text { Tingkat Ansietas Ibu } \\
\text { yang Merawat Anak } \\
\text { Pertama Usia 0-1 Tahun } \\
\text { Jurnal Perawatan } \\
\text { Indonesia, Vol } 3 \text { No } 1 \\
\text { Indeks : } \\
\text { Arjuna, Sinta, } \\
\text { DOAJ,Google scholer }\end{array}$ & $\begin{array}{lr}\text { Design: } & \text { Desain } \\
\text { penelitian } & \text { mengunakan } \\
\text { deskriptif } & \text { dengan } \\
\text { prosedur analisis statistik } & \text { Sampel: } 65 \text { anak berusia } \\
\text { 0-1 tahun } & \\
\text { Variabel: } & \text { tingkat } \\
\text { pendidikan } & \text { ibu, } \\
\text { berdasarkan pekerjaan } \\
\text { orang tua, berdasarkan } \\
\text { pemdapatan } \\
\text { Analisis: univariat dalam } \\
\text { bentuk tabel dan } \\
\text { frekuensi }\end{array}$ & $\begin{array}{l}\text { Tujuan: } \\
\text { Penelitian ini bertujuan untuk } \\
\text { mengidentifikasi tingkat ansietas } \\
\text { pada ibu yang merawat anak } \\
\text { pertama usia } 0-1 \text { tahun di Desa } \\
\text { Krajankulon Kec. Kaliwungu } \\
\text { Kab. Kendal. } \\
\text { Hasil : } \\
\text { Ibu yang merawat anak pertama } \\
\text { usia } 0-1 \text { tahun di Desa } \\
\text { Krajankulon Kec. Kaliwungu } \\
\text { Kab. Kendal Jawa Tengah } \\
\text { ratarata berusia } 24 \text { tahun, } \\
\text { mayoritas berpendidikan SLTA, } \\
\text { tidak bekerja, dan berpendapatan } \\
\text { cukup. Sedangkan tingkat } \\
\text { ansietas ibu yang merawat anak } \\
\text { pertama usia } 0-1 \text { tahun mayoritas } \\
\text { mengalami ansietas sedang.Perlu } \\
\text { intervensi keperawatan lebih } \\
\text { lanjut untuk mengatasi ansietas } \\
\text { ibu yang merawat anak pertama } \\
\text { usia 0-1 tahun melalui pendidikan } \\
\text { kesehatan ataupun terapi ansietas. }\end{array}$ & $\begin{array}{l}\text { Google } \\
\text { scholar }\end{array}$ \\
\hline 9. & 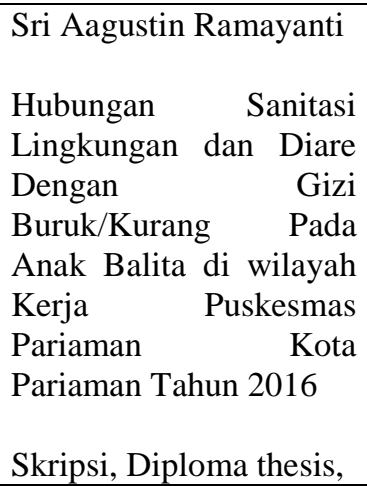 & $\begin{array}{l}\text { Design: kuantitatif } \\
\text { menggunakan desain } \\
\text { case control } \\
\text { Sampel: terdiri dari } 31 \\
\text { responden kasus dan } 31 \\
\text { responden kontrol } \\
\text { Variabel: sarana air } \\
\text { bersih, sarana } \\
\text { pembuangan kotoran, } \\
\text { sarana pembuangan air } \\
\text { limbah, sarana } \\
\text { pembuangan sampah }\end{array}$ & $\begin{array}{l}\text { Tujuan: } \\
\text { Untuk mengetahui hubungan } \\
\text { sanitasi lingkungan dan diare } \\
\text { pada anak balita gizi } \\
\text { buruk/kurang di wilayah kerja } \\
\text { Puskesmas Pariaman } \\
\text { Hasil : Sanitasi lingkungan } \\
\text { merupakan variabel yang } \\
\text { berhubungan dengan gizi buruk. } \\
\text { Kepada responden atau ibu yang } \\
\text { mepunyai anak balita diharapkan }\end{array}$ & Arjuna \\
\hline
\end{tabular}




\begin{tabular}{|c|c|c|c|c|}
\hline & $\begin{array}{l}\text { Universitas Andalas, } \\
\text { Juni } 2016 \\
\text { Indeks : Rama } \\
\text { Repositor, Sinta, Goole } \\
\text { Scholar }\end{array}$ & $\begin{array}{l}\text { Analisis: univariat dan } \\
\text { analisis bivariat dengan } \\
\text { uji statistik Mc Nemar } \\
\text { test }\end{array}$ & $\begin{array}{l}\text { selalu memperhatikan sanitasi } \\
\text { lingkungan. Bagi Puskesmas } \\
\text { Pariaman maka diharapkan } \\
\text { peningkatan integrasi antara } \\
\text { program penyehatan lingkungan } \\
\text { dengan program gizi dan }\end{array}$ & \\
\hline 10. & 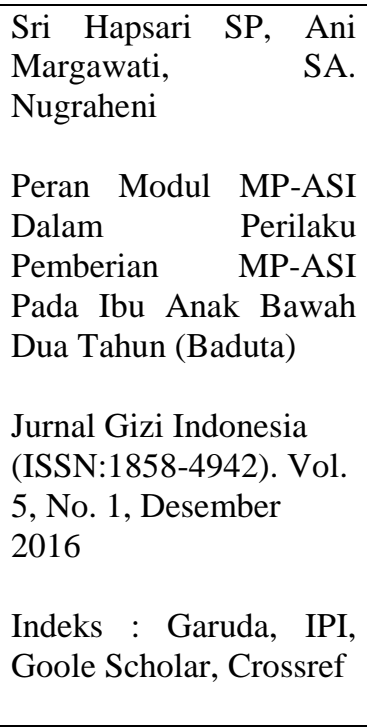 & $\begin{array}{l}\text { Design: } \\
\text { Experiment with non } \\
\text { randomized pre post-test } \\
\text { control group design. } \\
\text { Sampel: 24 ibu untuk } \\
\text { setiap kelompok } \\
\text { pelatihan modul MP-ASI } \\
\text { Variabel: pendidikan } \\
\text { ibu dalam menggunakan } \\
\text { modul MP-ASI } \\
\text { Analisis: Independent } \\
\text { Samples T-Test, Mann } \\
\text { Whitney, Paired T Test } \\
\text { dan Wilcoxon }\end{array}$ & $\begin{array}{l}\text { Tujuan : } \\
\text { menggunakan modidikan gizi } \\
\text { bahasa yang diperjelas dengan } \\
\text { gambar dan bisa dipelajari di } \\
\text { rumah diharapkan dapat } \\
\text { meningkatan perilaku pemberian } \\
\text { pada ibu anak baduta } \\
\text { Hasil : Pendidikan gizi } \\
\text { menggunakan modul MP-ASI } \\
\text { berperan dalam meningkatkan } \\
\text { perilaku ibu mengenai pemberian } \\
\text { MP-ASI pada kelompok } \\
\text { perlakuan, dan perubahan skornya } \\
\text { lebih tinggi dibanding kelompok } \\
\text { kontrol. Retensi perilaku } \\
\text { mengalami } \\
\text { bermakna pada } 2 \text { minggu dan } 1 \\
\text { bulan setelah perlakuan }\end{array}$ & $\begin{array}{l}\text { Portal } \\
\text { garuda. }\end{array}$ \\
\hline 11 & $\begin{array}{l}\text { Dwi, Febriani Bella, } \\
\text { Nur Alam Fajar, } \\
\text { Misniniarti } \\
\text { Hubungan Pola Asuh } \\
\text { Dengan Kejadian } \\
\text { Stunting Balita Dari } \\
\text { Keluarga Miskin di } \\
\text { Kota Malang } \\
\text { Jurnal gizi Indonesia } \\
\text { (The Indonesian Journal } \\
\text { Of Nutrition). Vol. 8, } \\
\text { No.1, Desember 2019 } \\
\text { Indeks: } \\
\text { Arjuna, Sinta2, Google } \\
\text { Scholer }\end{array}$ & $\begin{array}{l}\text { Design: observasional } \\
\text { yang menggunakan } \\
\text { pendekatan kuantitatif } \\
\text { dengan desain Studi } \\
\text { Cross Sectional } \\
\text { Sampel: Sampel } \\
\text { sebanyak } 100 \text { orang ibu } \\
\text { yang mempunyai balita } \\
\text { dari keluarga miskin } \\
\text { Variabel: pemberian } \\
\text { makan, kebiasaan } \\
\text { pengasuhan, kebersihan, } \\
\text { pelayanan kesehatan } \\
\text { Analisis: untuk melihat } \\
\text { hubungan antara variable } \\
\text { menggunakan uji Chi- } \\
\text { square }\end{array}$ & $\begin{array}{l}\text { Tujuan: Penelitian ini dilakukan } \\
\text { untuk mengamati bagaimana } \\
\text { pengaruh budaya pola asuh } \\
\text { berupa kebiasaan pemberian } \\
\text { makan, kebiasaan pengasuhan, } \\
\text { kebiasaan kebersihan dan } \\
\text { kebiasaan mendapatkan } \\
\text { pelayanan kesehatan terhadap } \\
\text { kejadian stunting balita dari } \\
\text { keluarga miskin di Kota } \\
\text { Palembang. } \\
\text { Hasil: Anak yang stunting } \\
\text { berhubungan dengan pola asuh } \\
\text { dalam keluarga berupa kebiasaan } \\
\text { makan, kebiasaan pengasuhan, } \\
\text { kebersihan dan pelayanan } \\
\text { kesehatan. Permasalahan anak } \\
\text { stunting tidak mutlak dikarenakan } \\
\text { keluarga yang miskin tetapi } \\
\text { disebabkan oleh peran pola asuh } \\
\text { dan kebiasaan keluarga }\end{array}$ & Portal garuda \\
\hline 12 & $\begin{array}{l}\text { Margawati, Ani, Astri } \\
\text { Mei Astuti } \\
\text { Pengetahuan Ibu, Pola } \\
\text { Makan dan Status Gizi } \\
\text { Pada Anak Stunting } \\
\text { Usia 1-5 Tahun di } \\
\text { Kelurahan Bangetayu, } \\
\text { Kecamatan Genuk, } \\
\text { Semarang } \\
\text { Jurnal Gizi Indonesia }\end{array}$ & $\begin{array}{l}\text { Design: } r \text { observasional } \\
\text { dengan pendekatan belah } \\
\text { lintang (cross sectional) } \\
\text { dengan } \quad \text { metode } \\
\text { kuantitatif dan kualitatif } \\
\text { Sampel: } 43 \quad \text { balita } \\
\text { stunting berusia } 12-60 \\
\text { bulan } \\
\text { Variabel: pengetahuan } \\
\text { ibu, asupan makanan } \\
\text { Analisis: food frequency } \\
\text { questionnaire (FFQ-SQ) }\end{array}$ & $\begin{array}{l}\text { Tujuan: untuk menganalisis } \\
\text { pengetahuan ibu, dan hubungan } \\
\text { pola makan dengan status gizi } \\
\text { pada anak stunting usia 1-5 tahun } \\
\text { di Kelurahan Bangetayu, } \\
\text { Kecamatan Genuk, Semarang } \\
\text { Hasil: Ibu dengan anak yang } \\
\text { menderita stunting mempunyai } \\
\text { pengetahuan dan persepsi yang } \\
\text { salah tentang stunting.Dan } \\
\text { Ibu dengan anak yang menderita } \\
\text { stunting tidak terlalu }\end{array}$ & \\
\hline
\end{tabular}




\begin{tabular}{|c|c|c|c|c|}
\hline & $\begin{array}{l}\text { (The Indonesian Journal } \\
\text { Of Nutrition), } 6 \text { (2), } \\
2018 \\
\text { Indeks: } \\
\text { Arjuna, Mendeley }\end{array}$ & & $\begin{array}{l}\text { mengkhawatirkan tentang kondisi } \\
\text { anaknya. Tidak ada hubungan } \\
\text { tingkat kecukupan energi, protein, } \\
\text { zat besi, dan seng, pada balita } \\
\text { stunting usia 1- } 5 \text { tahun di } \\
\text { Kecamatan Genuk }\end{array}$ & \\
\hline 13 & $\begin{array}{l}\text { Walangi, Rivoita G, } \\
\text { Olfie Sahelangi, Gita } \\
\text { Widodo } \\
\text { Pola Makan, Asupan Zat } \\
\text { Gizi, dan Status Gizi } \\
\text { Anak Balita Bawah } \\
\text { Garis Merah di Pesisir } \\
\text { Pantai Desa Tatengesan } \\
\text { dan Makalu Wilayah } \\
\text { Kerja Puskesmas } \\
\text { Pusomaen } \\
\text { Jurnal GIZIDO Vol.7 } \\
\text { No. 1 Mei 2015 } \\
\text { Indeks: } \\
\text { Indeks : Google Scholar, } \\
\text { DOAJ,Garuda, Sinta }\end{array}$ & $\begin{array}{l}\text { Design: observasional } \\
\text { dan deskriptif } \\
\text { Sampel: } 15 \text { anak } \\
\text { dibawah garis merah } \\
\text { (BGM) yang berusia 6- } \\
36 \text { bulan } \\
\text { Variabel: pola makan, } \\
\text { asupan zat gizi, status } \\
\text { gizi } \\
\text { Analisis: FFQ, dianalisis } \\
\text { dan disajikan dalam } \\
\text { bentuk tabel }\end{array}$ & $\begin{array}{l}\text { Tujuan: Untuk mengetahui } \\
\text { Asupan makanan anak yang } \\
\text { dibawah garis merah dan kaitanya } \\
\text { dengan terajadinya anak di bawah } \\
\text { garis merah di Pesisir pantai Desa } \\
\text { Tatengesan dan Makulu Wilayah } \\
\text { Kerja Puskesmas Pusomen } \\
\text { Hasil: Asupan gizi rata-rata anak } \\
\text { di bawah garis merah (BGM) } \\
\text { adalah: energy:663,7 kkal, } \\
\text { protein21,05 gram, lemak } 18 \\
\text { gram, dan karbohodrat } 112,55 \\
\text { gram. Hasil ini menunjukkan } \\
\text { kurangnya asupan gizi pada anak } \\
\text { balita }\end{array}$ & Portal garuda \\
\hline 14 & $\begin{array}{l}\text { Fitri, Dianatul, Dian } \\
\text { Shofiya } \\
\text { Hubungan ASI } \\
\text { Eksklusif dan Frekuensi } \\
\text { Sakit Pada Bayi di } \\
\text { Surabaya Barat } \\
\text { Amerta Nutrition (2020) } \\
\text { Indeks: } \\
\text { Garuda, Scopus }\end{array}$ & $\begin{array}{l}\text { Design: observasional } \\
\text { dengan desain cohort } \\
\text { prospective. } \\
\text { Sampel: sebanyak } 65 \\
\text { bayi pada Bulan April } \\
2019 \\
\text { Variabel: pengetahuan } \\
\text { ibu mengenai pemberian } \\
\text { ASI Eksklusif, frekuensi } \\
\text { sakit bayi analisis } \\
\text { Analisis: bivariat } \\
\text { univariat dan } \\
\text { (Chi Square Fisher Exact } \\
\text { Test) }\end{array}$ & $\begin{array}{l}\text { Tujuan: } \\
\text { Mengidentifikasi karakteristik } \\
\text { responden dan menganalisis } \\
\text { hubungan antara pemberian ASI } \\
\text { eksklusif dan frekuensi sakit } \\
\text { pada bayi } \\
\text { Hasil: } \\
\text { Adanya hubungan antara } \\
\text { pemberian ASI eksklusif dengan } \\
\text { frekuensi sakit pada bayi berusisa } \\
0-12 \text { bulan. Kuat hubungan } \\
\text { menunjukkan hubungan yang } \\
\text { lemah antara pemberian ASI } \\
\text { eksklusif dengan frekuensi sakit. }\end{array}$ & $\begin{array}{l}\text { Google } \\
\text { scholar }\end{array}$ \\
\hline 15 & $\begin{array}{l}\text { Masyudi, Mulyana,T.M. } \\
\text { Rafsanjani } \\
\text { Dampak Pola Asuh Dan } \\
\text { Usia Penyapihan } \\
\text { Terhadap Status Gizi } \\
\text { Balita Indeks BB/U } \\
\text { Aceh Nutrition Journal, } \\
\text { November 2019 } \\
\text { Indeks: } \\
\text { Garuda, } \\
\text { Mendeley Sinta, }\end{array}$ & 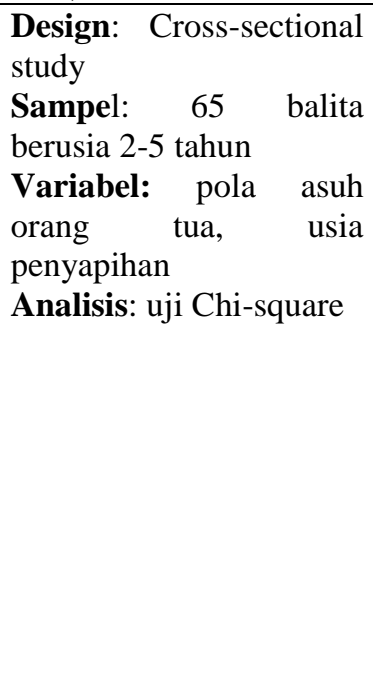 & $\begin{array}{l}\text { Tujuan:untuk mengetahui dampak } \\
\text { pola asuh dan usia penyapihan } \\
\text { terhadap status gizi balita. } \\
\text { Hasil: } \\
\text { Pola asuh balita dan usia } \\
\text { penyapihan mempunyai dampak } \\
\text { signifikan terhadap status gizi } \\
\text { balita berdasarkan indeks BB/U. } \\
\text { Dampak pola asuh yang kurang } \\
\text { baik sebesar } 3,6 \text { kali terhadap } \\
\text { status gizi kurang dibandingkan } \\
\text { pola asuh yang baik, dan usia } \\
\text { penyapihan dibawah } 20 \text { bulan } \\
\text { berdampak sebesar } 3,5 \text { kali } \\
\text { terhadap status gizi kurang pada } \\
\text { balita dibandingkan penyapihan } \\
\text { pada usia } 20 \text { bulan keatas. }\end{array}$ & $\begin{array}{l}\text { Google } \\
\text { scholar }\end{array}$ \\
\hline
\end{tabular}




\section{PEMBAHASAN}

Dari lima belas artikel tentang pola asuh dan status gizi anak, menyimpulkan bahwa pengaruh yang sangat kuat dalam status gizi anak adalah pola asuh orang tua yang terkhususnya ibu, karena ibu yang paling dekat dan yang sering berinteraksi dengan anak. Pengetahuan ibu sangat penting dalam meningkatkan status gizi anak yang baik mulai dari pengetahuan ibu dari masa kehamilan hingga anak lahir dan tumbuh dewasa. Tetapi juga dorongan dari keluarga lainya seperti ayah ataupun saudara kandung yang lain juga berpengaruh dalam memenuhi kebutuhan anak dan membantu tumbuh kembang anak. Tidak ada keterkaitan antara anak yang status gizi buruk/ kurang dengan keluarga yang miskin, semua tergantung cara pola asuh ibu yang baik terhadap anak, belum tentu anak yang dari keluarga kaya berstaus gizi baik dan begitu pula belum tentu anak dari keluarga miskin berstatus gizi buruk/kurang semua tergantung cara orang tua dalam memberika pola asuh kepada anak baik itu dari segi perawatan, pemberian ASI Eksklusif, pemberian makanan mendamping ASI anak ${ }^{7}$

Dari salah satu artikel yang berjudul "Karakteristik keluarga yang berhubungan dengan status gizi balita usia 6 - 59 bulan" menyatakan bahwa tidak ada hubungan antara besar keluarga dengan status gizi balita. Ada hungan antara pengetahuan gizi ibu dengan status gizi balita. Tidak ada hubungan antara pemanfaatan pelayanan kesehatan dengan status gizi balita. Tidak ada hubungan antara sanitasi lingkungan dengan status gizi balita. Karakteristik keluarga yang berhubungan secara bersama-sama dengan status gizi balita di wilayah Puskesmas II Sumbang Kabupaten Banyumas adalah pengetahuan gizi ibu ${ }^{8}$.

Berdasarkan dari lima belas artikel tersebut dapat disimpulkan bahwa Status gizi adalah keadaan tubuh sebagai akibat konsumsi makanan dan penggunaan zat-zat gizi. Status gizi dibedakan antara status gizi buruk, kurang, baik, dan lebih. Konsumsi makanan berpengaruh terhadap status gizi seseorang. Status gizi baik bila tubuh memperoleh cukup zat-zat gizi ${ }^{9}$. Gizi seimbang untuk bayi 0-6 bulan cukup hanya dari ASI. ASI merupakan makanan yang terbaik untuk bayi karena dapat memenuhi semua zat gizi yang dibutuhkan bayi sampai usia 6 bulan, sesuai dengan perkembangan sistem pencernaan, murah dan bersih. Oleh karena itu setiap bayi harus memperoleh ASI eksklusif yang berarti sampai usia 6 bulan hanya diberi ASI saja ${ }^{10}$.

Dari beberapa artikel mendapatkan hasil bahwa bayi yang mendapat ASI Eksklusif berasal dari ibu yang memiliki tingkat pendidikan SMA/SMK sederajat keatas dan memiliki umur 20 - 29. Dan ibu yang hanya memiliki pendidikan SMP sederajat kebawah dan umur yang udah termasuk tua memilki pengetahuan yang kurang dan wawasan yang sedikit mengenai pemberian ASI Eksklusif, sehingga kurang mengerti dalam pemberian ASI Ekslusif kepada bayi ${ }^{11}$. Pemberian makanan yang berkualitas dan kuantitasnya baik menunjang tumbuh kembang, sehingga bayi dapat tumbuh normal dan sehat/terbebas dari penyakit. Makanan yang diberikan kepada bayi dan anak akan digunakan untuk pertumbuhan badan, sehingga status gizi dan pertumbuhan dapat dipakai sebagai ukuran untuk memantau kecukupan gizi bayi dan anak ${ }^{12}$. Dari beberapa penelitian menunjukkan bahwa masih banyak orang tua yang belum paham dalam pemberian MPASI kepada bayi, masih banyak terdapat orang tua yang memberikan MP-ASI sebelum umur bayi 6 bulan dan orang tua yang belum paham dalam pemilihan bahan makanan dan cara pengolahan MP-ASI dengan baik $^{11}$.

\section{KESIMPULAN}

Berdasarkan data hasil penelitian dengan judul Kajian Pustaka Gambaran Pola Asuh dan Status Gizi Anak Umur 0 - 24 Bulandapat disimpulkan dari artikel-artikel ilmiah yang telah ditentukan bahwa status gizi anak berdasarkan gizi baik termasuk dalam kategori baik yaitu dengan rata-rata $67.5 \%$, status gizi anak berdasarkan gizi kurang $8.4 \%$, status gizi anak berdasarkan TB/U (pendek) $10.4 \%$ dan status gizi anak berdasarkan BB/TB (kurus) $6.7 \%$. Pola asuh pemberian ASI terdapat anak yang mendapatkan ASI lebih banyak dari pada anak yang tidak mendapatkan ASI. Pola asuh pemberian makan terdapat ibu yang memberikan MP-ASI lebih sedikit daripada ibu yang tidak memberikan MP-ASI secara baik kepada anak.

\section{SARAN}

1. Orang tua sebaiknya selalu memantau tumbuh kembang anak dengan memperhatikan pola asuh yang baik untuk anak

2. Sebaiknya pemerintah mendorong dan membantu masyarakat dalam meninjau tumbuh kembang anak, seperti contohnya memberikan fasilitas kepelayanan kesehatan didaerah

3. rakat yang kurang mampu dapat berobat ataupun mendapat makanan tambahan secara geratis

4. Sebaiknya peneliti memaparkan hasil yang lebih akurat lagi dan lebih jelas dalam membahas hasil agar pembaca mudah dalam memahami artikel.

\section{DAFTAR PUSTAKA}

1. Maradesa, Eirene, Nova H. Kapantow, Maureen I. Punuh, 2014. Hubungan Antara Asupan Energi Dan Protein Dengan Status Gizi Anak Usia 1-3 Tahun Di Wilayah Kerja Puskesmas Walantakan Kecamatan Longowan, Manado.

2. Fidiantoro, Nungki, Tedy Setiadi, 2013. Model Penentuan Satus Gizi Balita Di Puskesmas. Jurnal Sarjana Teknik Informatika. Yogyakarta. 
3. Aryastami, Ni Ketut, Ingan Tarigan, 2017. Kajian Kebijakan dan Pengaruh Masalah Gizi Stunting di Indonesia. Bogor.

4. Pratama, Riki Nur, 2013. Hubungan Antara Sanitasi Lingkungan Dan Personal Hygiene Ibu Dengan Kejadian Diare Pada Balita Di Keluruhan Sumurejo Kecamatan Gunung Pati Kota Semarang. Jurnal Kesehatan Masyarakat 2013. Semarang

5. Dahliansyah, Diffah Hanim, Harsono Salimo, 2018. Hubungan Pemberian ASI Eksklusif, Status Gizi, dan Kejadian Diare Dengan Perkembangan Motorik Pada 1000 Hari Pertama Kehidupan. Program Studi Ilmu Gizi Pascasarjana, Universitas Sebelas Maret

6. Khasanah, Dwi Puji, Hamam Hadi, Bunga Astria Paramashanti. 2016. Waktu pemberian Makanan Pendamping ASI (MP-ASI) Berhubungan Dengan Kejadian Stunting Anak Usia 6-23 Bulan di Kecamatan Sedayu. Jurnal Gizi Dan Dietetik Indonesia (hlm. 106). Yogyakarta

7. Bella, Febriani Dwi, Nur Alam Fajar, Misnaniarti, 2019. Hubungan Pola Asuh Dengan Kejadian Stunting Balita Dari Keluarga Miskin di Kota Palembang. Jurnal Gizi Indonesia. Palembang

8. Purwanti, Rachma, Erna Kusuma Wati, Setiyowati Rhardjo, 2016. Karakteristik Keluarga yang Berhubungan dengan Status Gizi Balita Umur 6-59 Bulan. Jurnal Gizi Indonesia. Purwokerto

9. Fidiantoro, Nungki, Tedy Setiadi, 2013. Model Penentuan Satus Gizi Balita Di Puskesmas. Jurnal Sarjana Teknik Informatika. Yogyakarta

10.Depkes, RI 2015. Pedoman Gizi Seimbang 2015. Dirjen Bina Gizi dan KIA Jakarta

11. Fitri, Dianatul, Dian Shofiya. 2020. Hubungan ASI Eksklusif dan Frekuensi Sakit Pada Bayi di Surabaya Barat. Amerta Nutrition. Surabaya Barat

12. Purba, Rudolf B, Fres A, dkk, 2018. Status Gizi Bayi4-6 Bulan yang Mendapatkan ASI Eksklusif dan ASI non Eksklusif di Puskesmas Kolongan Kecamatan Kalawat Kabupaten Minahasa Utara, Gizido Volume 10 No 1 Mei 2018, Manado

11. Fitri, Dianatul, Dian Shofiya. 2020. Hubungan ASI Eksklusif dan Frekuensi Sakit Pada Bayi di Surabaya Barat. Amerta Nutrition. Surabaya Barat 